$1 *$ к.е.н., доц., завідувач кафедри прикладної економіки, координатор Центру розвитку підприємництва «Бізнес-Інкубатор», Івано-Франківський національний технічний університет нафти i газу, e-mail: bi_if@ukr.net, ORCID ID: 0000-0001-5354-8502

\title{
ІНСТИТУЦІОНАЛЬНЕ СЕРЕДОВИЩЕ РОЗВИТКУ МАЛОГО ТА СЕРЕДНЬОГО ПІДПРИЕМНИЦТВА
}

Мета. Стаття присвячена вивченню сутності, структури та особливостей інституціонального середовища розвитку малого та середнього підприємництва (МСП) в Україні на сучасному етапі господарювання, враховуючи існуючі формальні та неформальні соціально-економічні інститути, чинники внутрішнього та зовнішнього впливу. Методика. Використано загальнонаукові методи аналізу та синтезу, економіко-логічні методи порівняння, групування, графічний метод, комплексної оцінки та інші. Результати. Головне завдання малого та середнього бізнесу - зайнятість, забезпечення добробутом більшої частини населення, вирішення нагальних проблем суспільства. Для становлення МСП в якості провідного сектору національної економіки потрібне відповідне сприятливе середовище, в першу чергу інституціональне. В роботі піднімаються питання та запропоновано ряд рекомендацій щодо відновлення довіри бізнесу до влади, формування позитивного іміджу підприємництва та партнерського ставлення владних структур до мікро-, малого та середнього бізнесу, тобто зміцнення неформалізованих інститутів розвитку МСП. Відмічено, що не менш важливу роль в інституціональній структурі розвитку малого та середнього бізнесу відіграють формалізовані інститути, наявність та тіснота взаємозв'язків тріади «держава - економіка - суспільство». Інституціональне середовище розглядається через призму взаємодії формалізованих і неформальних інститутів, що визначають рамкові межі поведінкових мотивів та умови функціонування й розвитку малого та середнього бізнесу. Наукова новизна. Уточнено економічний зміст та побудовано модель інституціональної структури функціонування і розвитку МСП - інституціональне середовище розвитку МCП, де узагальнено існуючі визначення та підходи до категоріального апарату нового інституціоналізму у сфері підтримки малого та середнього бізнесу, а також агреговано прикладні проблеми цієї сфери в Україні. Практична значимість. Комплексне відображення інституціонального середовища розвитку МСП дозволяє адекватно оцінити сформовані умови розвитку малого та середнього бізнесу в нашій країні, виокремити напрями розвитку системи підтримки МСП і врахувати окреслені пріоритети у відповідних програмних документах в межах державного управління МСП.

Ключові слова: інституціоналізм, інституціональне середовище, інститут, інституція, сприяння розвитку малого та середнього бізнесу

\section{Постановка проблеми}

Інституціоналізм - достатньо відома нині течія економічної науки, яка передбачає розгляд соціально-економічних відносин 3 позиції формування та функціонування базових інститутів. Водночас інституціональний підхід залишається надзвичайно актуальним в умовах сучасності, адже існує нагальна необхідність розбудови громадянського суспільства в нашій країні, забезпечити сталий розвиток, а трансформаційні процеси національної економіки у напрямі формування моделі соціально орієнтованого ринкового типу, на жаль, за роки незалежності України так і не отримали свого практичного втілення [3].

Одним 3 найважливіших інститутів розвитку національної економіки вважаємо мале та середнє підприємництво (МСП), оскільки воно характеризується унікальними якостями, володіє особливим потенціалом розвитку [15]. Формуючи, відповідно, сприятливі умови та належне інституціональне середовище для функціонування та розвитку МСП, ми тим самим мали б посилювати трансформаційноінституційні зміни економічної системи, забезпечувати «де-юре» i «де-факто» соціалізацію ринкового механізму, прискорювати інтенсивність дії особливих характерних рис малого та середнього бізнесу. Проте таке твердження потребує свого обгрунтування, a категорія «інституціональне середовище розвитку МСП» $\epsilon$ недостатньо вивченою i розглядається науковцями та практиками в різних контекстах. Цікавим також $\epsilon$ 
дослідження впливу інституціонального середовища, інституційних чинників на функціонування МСП, вивчення взаємозв'язків та взаємозалежностей в межах даної системи, розгляд особливостей основних інститутів, інституцій сприяння розвитку МСП.

\section{Аналіз останніх досліджень і публікацій}

Проблематикою інституціоналізму та інституційного забезпечення економічної політики займалося чимало видатних вчених, серед вітчизняних слід назвати таких: В.Геєць [5], А. Гриценко, I. Манцуров, С. Король, В.Тарасевич, С. Турчіна, О. Чубарь [13].

Пошуком особливостей інституційного (інституціонального) середовища у розвитку МСП також займалося чимало науковців, зокрема: Д. Волчек [21], Н. Остапенко [19], Я.Бережний, Д. Ляпін, Д. Покришка та Я.Жаліло [2], О. Сич та І. Нітман [9], С. Бойда [4], Ж. Шевчук та Н. Федорчук [14], О.Стрижак [10], О. Ляховець [8], А. Краєвська [6], Ю. Райта та багато інших.

Проте, незважаючи на численні та грунтовні праці вітчизняних та іноземних дослідників, питання щодо сутності та структури інституціонального середовища розвитку МСП, механізмів впливу його елементів на малий та середній бізнес залишаються не вирішеними, а практичні проблеми, які існують у сфері підтримки МСП нашої країни, суттєво актуалізують предмет розгляду даної статті.

\section{Формулювання цілей статті}

Предметом розгляду та метою в межах цієї праці $\epsilon$ визначення сутності, структури, вивчення особливостей інституціонального середовища розвитку малого та середнього бізнесу в Україні, характеристика основних його інститутів, інституцій та механізмів їхньої взаємодії задля активізації прогресивних змін національної економіки та суспільства за рахунок формування та забезпечення сприятливих умов для функціонування та розвитку МСП.

\section{Виклад основного матеріалу дослідження}

Розглядаючи інституціоналізм, першочергово звернімося до праці Я. Бережного [1], в якій він визначив інституційний підхід як «модерний» для розвитку суспільств та обгрунтовував особливості трансформації новітніх напрямів інституційної економічної теорії у формуванні державної економічної політики. Відмітимо, що такі погляди $\epsilon$ достатньо близькими і для нашого сприйняття, адже нам цілком імпонує як автор, розглядаючи економічний розвиток у міждисциплінарній інституційній площині «економіка, політика i соціальна поведінка», обгрунтовує потрібність формування державної політики на основі гнучких поведінкових рамок господарюючих суб'єктів - «скоріше на базі духу закону, ніж на самому законі» [1]; проте він залишає відкритими питання структури інституційних змін, місця дійових осіб та держави у їх перетворенні.

В. Геєць [5], доводячи потрібність інституційних перетворень та довіри населення до таких процесів, наголошує на важливості цілеспрямованого розвитку інститутів громадянського суспільства при проєкті модернізації у тріаді «суспільство держава - економіка», на необхідності панування законності, порядку та відповідальності через підтримання самою державою знову ж таки «духу закону».

Підтримаємо згадані вище твердження в контексті необхідності формування довіри населення, суспільства, і бізнесу зокрема, до діяльності державних структур, тобто потрібності дії неформальних інститутів. Які б закони, правила, ініціативи не впроваджувалися, їх реалізація можлива лише за умови довіри цільових груп (бенефіціарів) до ключових інституцій, які такі нововведення запроваджують. Довіра складне поняття, що формується довготривалий час на базі використання набору цінностей та дотримання ряду норм, правил і принципів. Йдеться насамперед про такі обов'язкові елементи (компоненти) при функціонуванні інституцій, в нашому випадку - сфери сприяння розвитку МСП:

- penутація - виконання взятих на себе зобов'язань, доброчесність, етика професійної діяльності, нетерпимість до корупції та стратегічна орієнтація на людиноцентричність;

- прозорість, публічність, гласність та комунікація - першочергово щодо використання ресурсів / капіталу, фінансової звітності за витрачанням коштів, поточної діяльності загалом, роботи зі споживачами послуг тощо;

- демократичність управління 
демократичні засади переобрання та передачі влади, горизонтальні зв'язки між ланками організаційної структури, дієвість принципу «лідером може бути кожен».

Не менш важливим для формування довіри бізнесу до влади є і партнерське ставлення державних інституиій до бізнес-структур, наявність спільних проєктів на умовах партнерства, формування позитивного іміджу підприємницької діяльності. На жаль, органи державної влади та місцевого самоврядування зачасту сприймають бізнес не як рівного партнера у роботі, а трактують суб'єктів підприємництва виключно із фіскальних мотивів - розглядають в якості платників податків. Тут доречно відмітити, що основною функцією малого бізнесу $\epsilon$ самозайнятість, скорочення рівня безробіття, забезпечення доходами широких верст населення, вирішення нагальних соціальних проблем, проте геть не сплата платежів до бюджетів.

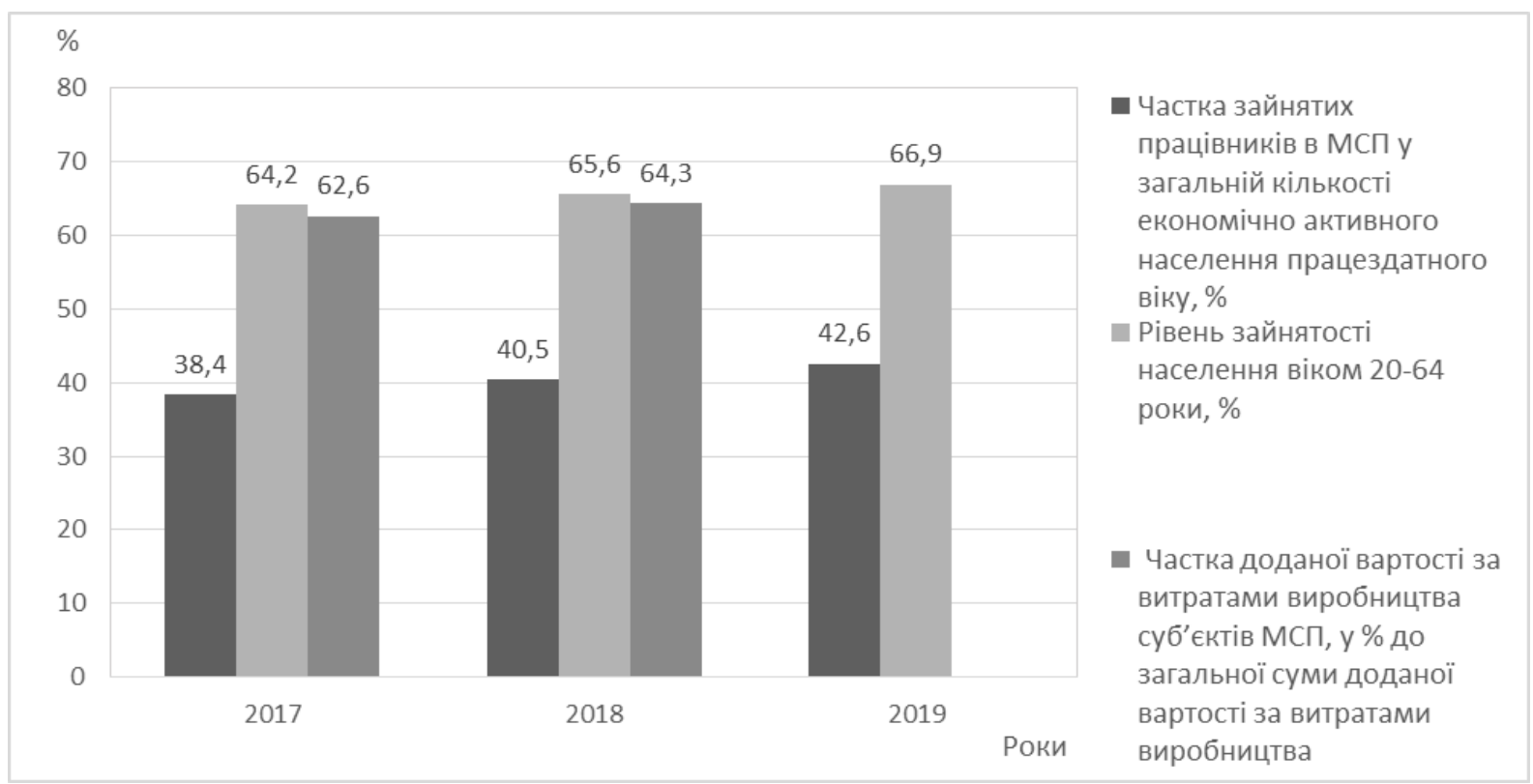

Рис.1 Роль МСП у зайнятості населення та у створенні доданої вартості в Україні у 2017-2019 рр.

Дюерело: сформовано автором з використанням даних [12]

Як бачимо 3 рис. 1., відсоток зайнятих в МСП у загальній чисельності робочої сили працездатного віку залишається не надто високим в Україні - 42,6\% у 2019 році. Водночас, у 35 країнах - членах Організації економічного співробітництва та розвитку на МСП припадає 50-60\% доданої вартості [18] та понад дві третини усіх робочих місць у світі [20]. Це підтверджує необхідність інтенсифікації розвитку МСП в нашій країні, першочергово задля активізації економічної активності населення.

Отож, МСП мало б бути першим стратегічним партнером для владних структур, зокрема і на місцях. Проте, на жаль, майже за тридцять років функціонування інституту приватної власності в незалежній Україні, більшості населення досі потрібно роз'яснювати основи бізнесу, пояснювати чому це цікаво і чим вигідно. Формуванням позитивного іміджу підприємництва повинно розпочинатися ще у садочку, у школі, а розвиток i примноження цих понять протягом усього періоду життєдіяльності людини.

Окрім відсутності «підприємницького» або ж «бізнесового» виховання для дітей, в суспільстві існує стереотип негативу ініціативності, лідерства, до прояву креативності тощо. Це все $\epsilon$ прямими пережитками радянського минулого, внаслідок чого дорослі особи бояться брати на себе відповідальність за рішення, бути підприємцями, i $є$ по суті «дорослими дітьми». Це також вважаємо важкою проблемою, боротися 3 якою потрібно 
системно, комплексно, формуючи належне сприятливе мікросередовище, комфортний мікроклімат для ведення бізнесу, першочергово - створювати відповідне інституціональне середовище розвитку МСП, яке б ефективно поєднувало як формальні, так i неформальні соціально-економічні інститути.

Водночас існує й проблема відсутності культури ведення підприємництва, етики, доброчесності, належного рівня репутації та сочіальної відповідальності бізнесу. Прикро, адже в більшості випадків суб'єкти підприємництва не приділяють належної уваги згаданим вище цінностям, ми ж рекомендуємо сприймати їх як обов'язковий компонент у своїй діяльності. Це все підтверджує брак усталених норм, правил поведінки у суспільстві.

Повертаючись до

проблематики інституціональної теорії, відмітимо аналіз П.Левіна [7], де чітко виокремлено класичний напрям та новий напрям інституціоналізму. На противагу інституціоналістам-класикам, неоінституціоналісти дотримуються неокласичних напрямів, що призводить до абсолютизації ринкових методів при регулюванні діяльності галузей соціальної інфраструктури [7].

I. Тарасова [11], розглядаючи інституціональне забезпечення розвитку економіки i суспільства, також виділяє особливості «старого» та «нового» інституціоналізму. Автор досить вдало, як на наш погляд, наголошуе на основних проблемах «нового» інституціоналізму (необ'єктивне оцінювання інститутів, складність виміру ефективності та сталого функціонування в такому стані); обгрунтовує існуючі дві концепції, що описують дані проблеми:

- концепція «інституціональної пастки» (визначення неефективності стійких норм поведінки, для подолання такої «пастки» треба або зменшити трансакційні витрати альтернативної норми і трансформаційні витрати переходу від однієї норми до іншої, або ж збільшити трансакційні витрати неефективної норми, щоб сталася відмова слідувати їй);

- концепція дисфункції інститутів (існування неефективних норм $\epsilon$ закономірним результатом господарської динаміки, при якій відбувається розлад та/або зниження якісного стану функцій інститутів, зниження ефективності їх виконання i фіксація цього в часі) [11].

Згадані проблеми особливо гостро відчуваються і у системі сприяння розвитку МСП. Приміром, дискусії щодо доцільності функціонування структур підтримки МСП, оцінка ефективності заходів, які впроваджуються інституціями сприяння розвитку бізнесу, досі залишаються мега актуальними станом на сьогодні. Як i y владних кабінетах, так i в суспільстві досі виникає дилема та піднімаються питання на кшталт: «Чи потрібно підтримувати малий та середній бізнес чи це самодостатній сектор економіки, що не потребує сприяння?», «Чи варто виділяти кошти на підтримку МСП і яким чином це забезпечити?» та багато інших у такому спрямуванні. Так, малий і середній бізнес є особливим сектором економіки, який може вирішувати ряд важливих суспільних проблем, на «першій ланці» прививати культуру ведення бізнесу для населення, тому має бути окремим об'єктом державної політики підтримки.

Загалом, обгрунтування потрібності та оцінка ефективності інститутів вимагає розуміння сутності та економічного змісту цього поняття, адже як і немає «чистих» інституціоналістів, так само існує безліч підходів та поглядів до трактування терміну «інститут».

Інститути - це «...словесний символ для кращого опису низки суспільних звичаїв», переважний i постійний спосіб мислення, який став звичкою для групи або звичаєм для народу, до якого ми пристосовуємо своє життя...» [16].

Дуглас Норт [17] визначив інститути як «...набір правил, процедуру відповідностей, моральне і етичне поводження індивідуумів в інтересах максимізації багатства; це розроблені людьми формальні (закони, конституціï) i неформальні (договори i добровільно прийняті кодекси поведінки) обмеження, а також фактори примусу, що структурують їх взаємодію. Інституційний розвиток економіки відбувається під впливом взаємодії між інститутами і організаціями, коли перші визначають «правила гри», а другі $\epsilon$ «гравцями» [17].

Отож, за рівнем формалізації інститути поділяють на формальні та неформальні; в даному контексті, на наш погляд, добрим $є$ доробок I. Тарасової [11], де вона виділяє серед формальних економічних інститутів 
такі: права власності і правові інститути, політичні інститути, фінансові інститути, організація кредитної та банківської систем, інститути тіньової економіки; до неформальних відносить: рівень громадянської думки, рівень економічного мислення, рівень людського капіталу, менталітету, рівень соціальної відповідальності бізнесу [11].

Вважаємо доречним першочергово зосереджувати увагу на функціонуванні формальних чи так званих «формалізованих» інститутів економіки та суспільства. Проте воліємо також розглядати інструменти i механізми, які поєднуватимуть формальні та неформальні економічні, політичні, суспільні інститути, що стимулюватимуть до розвитку як об'єкт, на який вони впливають, так i самих себе.

I. Тарасова [11]: «...проблема неефективності системи інститутів України полягає в недосконалому інституціональному середовищі ї функціонування, що обумовлюється слабкою дієздатністю формальних інститутів (правових, фінансових, політичних, інтелектуальних, технологічних, державних, професійних тощо), наявністю «інституційних пасток» у владі, економіці та суспільстві та недосконалістю неформальних інститутів (рівень громадської культури, наявність людського капіталу, довіра суспільства до влади)». Переконливо погоджуємось 3 цим твердженням і вважаємо доречним розглядати інститути комплексно, беручи до уваги взаємозв'язки між ними, інституційні чинники в межах однієї інституціональної структури, тобто в межах інституціонального середовища сфери розгляду.

Інституціональне середовище розвитку МСП є насправді взаємодією складових і передбачає співіснування ряду економічних, політичних та суспільних інститутів, як формальних, так і неформалізованих, що знаходяться під впливом зовнішніх та внутрішніх чинників (рис. 2).

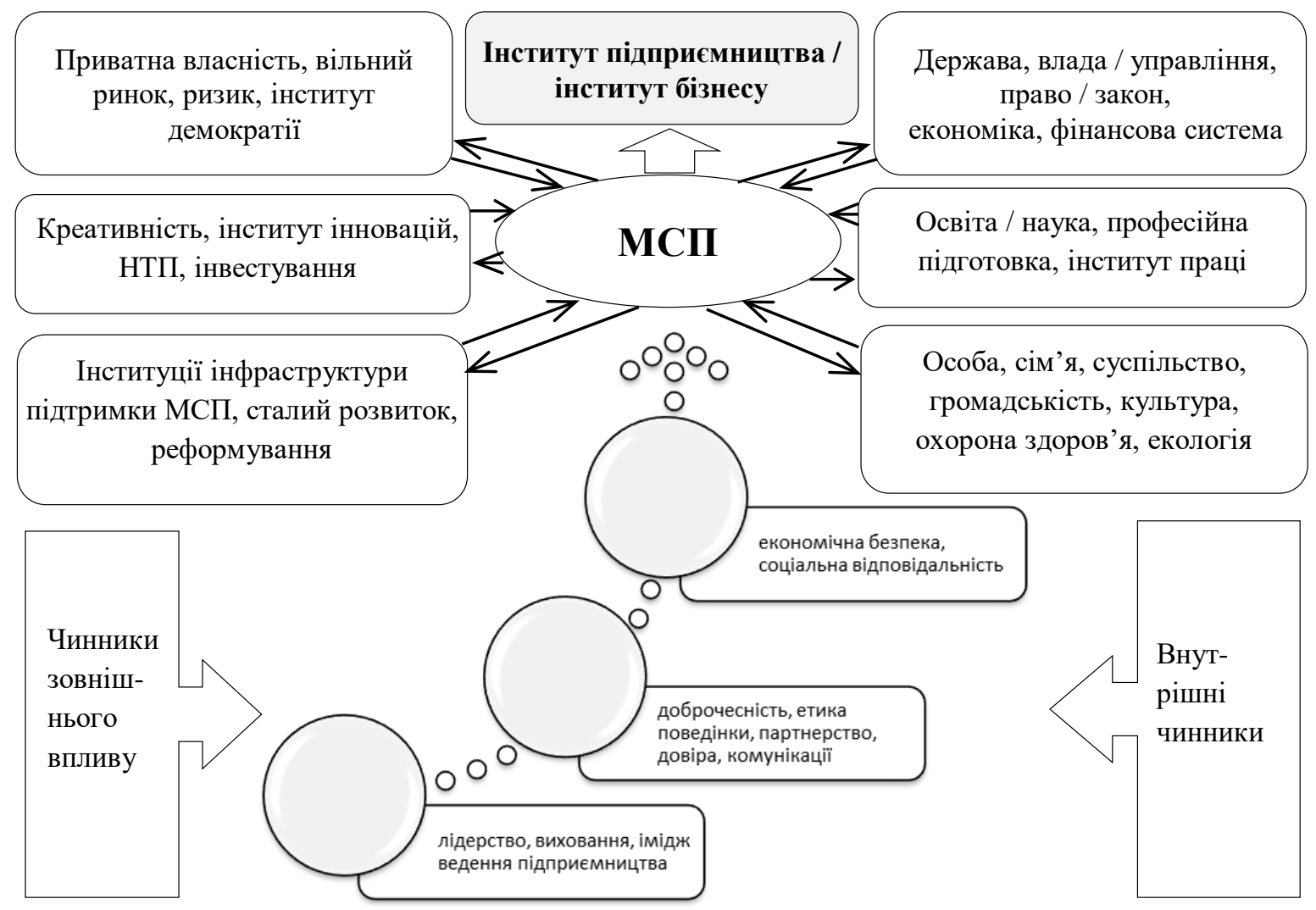

Рис. 2 - Інституціональне середовище розвитку МСП

Джерело: розроблено автором 
Охарактеризуємо основні інститути представленого вище середовища (див. рис.2): - інститут приватної власності, функціонування законів ринку, в тому числі конкуренції між учасниками, ризикової діяльності, демократичних принципів щодо вільного вибору ресурсів / продукції, постачальників / споживачів тощо (інститут демократичного устрою передбачає функціонування лібералізму та неолібералізму в економічній політиці держави);

- креативність, інновації, науковотехнічний прогрес (НТП), технології, інвестування та формування належного інвестиційного клімату - заснування та існування малих бізнесів є неможливим без функціонування інституту інновацій, запуску стартаптів, розвитку нових, креативних індустрій, оскільки МСП за своєю природою $є$ цілком інноваційними суб'єктами господарювання;

- iнфраструктурне забезпечення розвитку МСП включає в себе ряд інститутів та інституцій підтримки підприємництва, які забезпечують реалізацію політики, спрямованої на малий та середній бізнес (до слова, вважаємо даний інститут одним із ключових для розвитку МСП);

- держава як інститут права, закону, законності, правопорядку, інститут влади, управління, економічна система країни (інститут виробництва, дохід, оподаткування, зайнятість / безробіття, окремі сфери економічної діяльності, інфраструктура), фінансово-кредитна система, включаючи фінанси, фінансові інституції, інститути платіжно-розрахункових відносин, грошового обігу тощо. Безперечно, функціонування даних інститутів в країні відіграє провідну і змістовно визначальну роль у напрямі політики управління розвитком МСП;

- інститут освіти, науки, професійної підготовки як неформальної освіти, яка сьогодні набуває важливої ролі в суспільстві, інститут праці. Найбільш цінним ресурсом в Україні $\epsilon$ інтелектуальний капітал, збереження та розвиток якого $є$ важливими для нації та існування держави. Людський потенціал країни $є$ систеутворюючою складовою і у розвитку МСП;

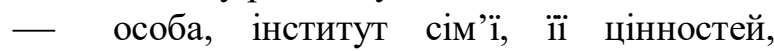
традицій, суспільства та усіх суспільних інститутів, громадськості, інститут культури / мистецтва, охорони здоров'я / медицини, екологічної складової, якості життя, довкілля, політики природокористування та інше.

Кожен із перелічених інститутів прямо діє на МСП, скоріше у контексті домінуючої політики управління за допомогою різноманітних інструментів прямого та непрямого регулювання. Відмітимо, що, не зважаючи на свою економічну незалежність, малий та середній бізнес як об'єкт управління потребує такого регулювання / дерегулювання і перебуває у прямій залежності від наявності та дієздатності тих чи інших інститутів. Згадані інститути можуть бути поширені на бізнес в цілому, і на велике підприємництво в тому числі, проте МСП є тією «першою ланкою» взаємодії, тому найуразливіше реагує на зміни у поведінці інститутів.

Серед чинників зовнішнього середовища, що впливають на розвиток МСП: тенденції розвитку світової економіки, кон'юнктура міжнародних ринків збуту продукції, рівень «відкритості» національної економіки, тенденції глобалізаційних процесів, сальдо та структура зовнішньо-економічної діяльності підприємств, відповідність технологій вітчизняних підприємств НТП, рівень боргової безпеки.

Головними внутрішніми чинниками впливу $€: \quad$ нормативно-правове забезпечення започаткування та ведення підприємництва, системи підтримки малого та середнього бізнесу, регуляторна політика, система оподаткування, політика та інструменти державного сприяння розвитку МСП, рівень розвитку суспільних інститутів та громадянського суспільства загалом, динаміка та тенденції розвитку окремих сфер економічної діяльності, рівень зайнятості, безробіття, інфляція, курс національної грошової одиниці, обсяг ВВП на душу населення, індикатори соціально-економічної безпеки держави та підприємництва, процеси децентралізації в країні та інші.

Підсумовуючи, спробуємо узагальнити існуючі твердження i визначити інституціональне середовище розвитку МСП як сукупність формальних і неформальних базових інститутів, що визначають межі й умови функціонування та розвитку малого i середнього бізнесу в країні.

На превеликий жаль, відзначимо, що сьогодні вітчизняна інституціональна структура розвитку МСП не функціонує 
належним чином. У 2019 році Україна зайняла 64 місце у рейтингу легкості ведення бізнесу Doing Business i аж 104 позицію у рейтингу Global Competitiveness Report за субіндексом «Інституції (державні та суспільні установи)» [12]. Задля покращення ситуації слід сформувати відповідне інституціональне середовище для функціонування та розвитку МСП, в першу чергу забезпечити ефективне функціонування формалізованих соціально-економічних інститутів, що і посилюватиме зміцнення неформальних. Провідна роль у цьому процесі належить державним органам влади та місцевого самоврядування при їх тісній взаємодії із суспільними (громадськими) інститутами.

Класично існує думка, що наявність та ефективність формалізованих інститутів формують неформальні. Проте, в умовах розвитку громадянського суспільства, виникнення соціально відповідальних інституцій відповідно, можемо підтвердити і міцний зворотній зв'язок, тобто коли наявність неформальних інститутів провокує і зобов'язує створення та забезпечення ефективності формалізованих 3 них. Тому вважаємо найоптимальнішою формою взаємодії належне інституціональне середовище, яке i поєднуватиме та посилюватиме як зв'язки між інститутами, так i ïx самих: формальних і неформальних. До слова, переконані, що серед конкурентних переваг України $\epsilon$ значний потенціал до активного розвитку неформальних економічних, суспільних та політичних інститутів, високий рівень самоорганізації та взаємодопомоги у скрутну хвилину - тому підтвердження.

\section{Висновки}

Проведене дослідження дозволяє зробити деякі висновки і окреслити перспективи:

1. Проблематика інституціоналізму, зокрема «нового» інституціоналізму, проектується і на систему підтримки МСП. Особливо гострими в цьому контексті $\epsilon$ питання доцільності існування та функціонування інституцій сприяння розвитку малого та середнього бізнесу, ефективності виконання ними заходів підтримки, фінансування окремих програм та проєктів.

2. Узагальнюючи прояви інституціоналізму у сфері сприяння розвитку МСП в Україні, відмічено, що важливими завданнями $\epsilon, 3$ однієї сторони, відновлення довіри бізнесу до владних структур, а 3 іншого боку формування позитивного іміджу ведення підприємницької діяльності та необхідність партнерського, паритетного ставлення держави до суб'єктів МСП. Тут йдеться про забезпечення функціонування неформальних економічних та суспільних інститутів, які працюватимуть поряд 3 формалізованими в межах одного належно сформованого інституціонального середовища розвитку МСП.

3. Інституціональне середовище розвитку МСП $є$ взаємодією базових інститутів, має включати міцні та ефективні формалізовані інститути - інституції інфраструктури підтримки малого та середнього бізнесу, що обгрунтовується цінністю продукту таких структур (потрібність бізнес-послуг, наявність «свого» споживача та окрема ніша на ринку консалтингу).

4. В центрі уваги інституціональної структури розвитку МСП безпосередньо $€$ малий та середній бізнес, який, розвиваючись, забезпечуе зміцнення інституту підприємництва як такого (в якості самостійної, ризикової діяльності) та інституту бізнесу (як явища, що створює економічний ефект та вирішує ряд соціальних проблем). Надзвичайно важливим інститутом інституціонального середовища вважаємо систему інфраструктурного забезпечення підтримки МСП, на формування якої потрібно спрямовувати зусилля усіх суб'єктів інституціональної структури, а першочергово - органів виконавчої влади i місцевого самоврядування.

5. Охарактеризовано прямий вплив складових інституціонального середовища на розвиток МСП, зокрема: інституту приватної власності, компонентів вільного ринку, демократії, держави, інституту права, економіки, фінансової системи, інститутів та інституцій інфраструктури підтримки МСП, інституту освіти, інституту праці, охорони здоров'я та інших, тобто основних інститутів ланцюжка «держава - економіка суспільство». Інституціональна структура розвитку МСП підтверджує i зворотній зв'язок, коли МСП забезпечує зміцнення згаданих вище економічних, політичних та суспільних інститутів в країні. Це ще більше 
актуалізує необхідність розвитку малого та середнього бізнесу, особливо для країн із неусталеними принципами та нормами неолібералізму у практичній площині.

\section{BEREZHNYTSKA U..$^{*}$}

$1 * \mathrm{PhD}$ of Economic Sciences, Associate Professor, Head of Applied Economy Department, Coordinator of Entrepreneurship Development Centre "Business-Incubator", Ivano-Frankivsk National Technical University of Oil and Gas, e-mail: bi_if@ukr.net, web: https://nung.edu.ua ORCID ID: 0000-0001-5354-8502

\section{INSTITUTIONAL ENVIRONMENT OF SMALL AND MEDIUM-SIZED ENTREPRENEURSHIP DEVELOPMENT}

The purpose. The article is devoted to the study of the essence, structure, features of the institutional environment of small and medium-sized entrepreneurship (SME) in Ukraine at the modern stage of economy, taking into account existing formal and informal socio-economic institutes, factors of internal and external influence. Methods. General scientific methods of analysis and synthesis, economic and logical methods of comparison, grouping, graphical method, complex assessment and others are used. The Results. The main task of small and medium-sized businesses is employment, ensuring the welfare of the majority of the population, solving urgent problems of society. The promotion of SMEs as the leading sector of the national economy requires an appropriate favorable environment, primarily institutional. The paper raises issues and offers a number of recommendations for restoring business confidence in government, forming a positive image of entrepreneurship and partnership of government agencies to micro-, small and medium businesses, namely strengthening informal institutions for SME development. It were noted that formalized institutions, the presence and closeness of the relationship of the triad "state economy - society" play no less important role in the institutional structure of small and medium-sized business development. The institutional environment is considered through the prism of interaction of formalized and informal institutions that define the framework boundaries of behavioral motives and conditions for the functioning and development of small and medium-sized businesses. Scientific novelty. The economic content and the model of the institutional structure of functioning and development of SMEs is specified - the institutional environment of SME development, which summarizes the existing definitions and approaches to the categorical apparatus of new institutionalism in the field of small and medium-sized business support, and aggregates applied problems in Ukraine. The practical significance. Complex reflection of the institutional environment of the SME development allows to adequately assessing the current conditions for the development of small and medium-sized businesses in our country, to identify areas of SME support system and take into account the priorities in the relevant policy documents within state management toward SME.

Keywords: institutionalism, institutional environment, institute, institution, support of small and medium-sized business development

\section{REFERENCES}

1. Berezhny Ya. V. Institutional principles of state economic policy / Ya. V. Berezhny // Effective economy. Dnipropetrovsk State Agrarian and Economic University, 2011. - No 9. - 3 p. [in Ukrainian].

2. Berezhnyi Ya. V. Problems and ways of forming a favorable institutional environment for business in Ukraine: an analytical report / Ya. V. Berezhnyi, D. V. Lyapin, D.S. Pokryshka: edited by E. A. Stinging. - K.: NISI, 2014. - 80 p. - (Series "Economics", issue 13) [in Ukrainian].

3. Berezhnytska U. B. Socialization of the economy of Ukraine as an objective necessity of market transformation / U. B. Berezhnytska // Modern management technologies in terms of transformation of socio-economic relations: materials all-Ukrainian. scientific-practical conf. (Ivano-Frankivsk, April 19-20, 2018). - Ivano-Frankivsk: IFNTUNG, 2018. - P. 104-107 [in Ukrainian].

4. Boyda S. V. Institutional problems of business environment formation in Ukraine / S. V. Boyda // Young scientist. - 2016. - No 5 (32). - P. 23-26 [in Ukrainian].

5. Heyets V. M. Institutional transformations and social development / V. M. Geets // Economics and forecasting. 2005. - No 2, P. 9-36. [in Ukrainian].

6. Kraevska A. Development of entrepreneurship in terms of institutional uncertainty / A. Kraevska // Vinnytsia National Technical University. - 2015. - 9 p. [in Ukrainian].

7. Levin P. B. Institutionalism as a theoretical basis for the functioning of social infrastructure / P. B. Levin // Economic Science. - 2010 - No 2/2020. - P.27-29 [in Ukrainian].

8. Lyakhovets O. Formation of the institutional environment in the process of modernization of the economy / O. Lyakhovets // Economy and region. - 2014. - No 4 (47). - P. 113-119 [in Ukrainian]. 
9. Sych O. Analysis of the impact of the institutional environment on the development of small and medium enterprises / O. Sych, I. Nitman // Problems and prospects of economics and management. - 2017. - No 2 (10). - P. 111-117 [in Ukrainian].

10. Strizhak O. O. Theoretical foundations of the study of the institutional environment of human development / O. O. Strizhak // Bulletin of Mykhailo Ostrogradsky KrNU. - 2016. - Output 4/2016 (99). - P. 115-123 [in Ukrainian]. 11. Tarasova I. I. Institutionalism in the methodology of scientific discourse / I. I. Tarasova // Actual problems of economy. - 2015. - No 2. - P. 73-78. - Available at: http://nbuv.gov.ua/UJRN/ape_2015_2_12 [in Ukrainian].

12. Sustainable development goals-2020.Monitoring report//State Statistic Service of Ukraine. URL: http://www.ukrstat.gov.ua/csr_prezent/ukr/st_rozv/publ/SDGs\%20Ukraine\%202020\%20Monitorin_12.2020ukr.pdf. 13. Chubar O. G. Institutes and institutional environment: theoretical generalizations of the principles of economic development / O. G. Chubar // Scientific herald of the Uzhhorod university : collections of scientific works. Uzgorod : UzNU, 2013. - Output 3(40). - P.98-104 [in Ukrainian].

14. Shevchuk Zh. A. Problems of development of the institutional environment in Ukraine / Zh. A. Shevchuk, N. V. Fedorchuk // Scientific herald of the Uzhhorod national university. - 2016. - Output 3, part. 3. - P. 141-144 [in Ukrainian].

15. Berezhnytska U. Innovative Model of SME Development / Uliana Berezhnytska // Proceedings of the 2019 7th Conference on Modeling, Development and Strategic Management of Economic System (MDSMES 2019) : Series: Advances in Economics, Business and Management Research (Ivano-Frankivsk, October 24-25, 2019). https://www.atlantis-press.com/proceedings/mdsmes-19/125919204. - p. 139-143.

16. Hamilton W. Institution. Encyclopedia of the Social Sciences. - N.-Y., 1932 p. - V. VIII. - 84 p.

17. North Douglass. Institutions, Institutional Change and Economic Performance, 1990. North D. Institutions, institutional change and the functioning of the economy. Translation from English. A.N. Nesterenko. - M., 1997 // 18. Electronic publication: Center for Humanitarian Technologies. - Available at: https://gtmarket.ru/laboratory/basis/6310.

19. OECD SME and Entrepreneurship Outlook 2019. URL: https://www.oecd.org/industry/smes/SME-OutlookHighlights-FINAL.pdf.

20. Ostapenko N. Features of small business development in the CIS countries: does institutional environment affect / N. Ostapenko // Studies and Scientific Researches. Economic Edition. - 2014. - No 19. - p. 51-59.

21. The power of small: unlocking the potential of SMEs // International Labour Organization. URL: https://www.ilo.org/infostories/en-GB/Stories/Employment/SMEs\#intro (published Oct. 2019).

22. Volchek D. Sctructural Model of Institutional Environment Influence of International Entrepreneurship in Emerging Economies / D. Volchek, S. Saarenketo, A. Jantunen // Palgrave Macmillan. - 2015. - p. 190-216.

Стаття надійшла до редакції: 28.02.2021

Received: 2021.02.28 